\title{
Behaviors of Some Soybean Cultivars (Glycine max L.) Yield to Planting Dates and Different Phosphorus Fertilizer Rates
}

\author{
Kandil A.A. ${ }^{1}$; A.E. Sharief ${ }^{1 *}$, A.N.Ramadan ${ }^{2}$ \\ ${ }^{1}$ Agronomy Department, Faculty of Agriculture, Mansoura University, Egypt \\ ${ }^{2}$ Ministry of Agriculture, Egypt \\ *Corresponding Author
}

\begin{abstract}
Soybean production components such as planting date, cultivars and phosphorus fertilizer rates affected soybean yield. Two field experiments conducted in extensive field at El-Gahrbia district, Egypt during 2015 and 2016 seasons. The goal of this research was aimed to investigate the influence of sowing date at $1^{\text {th }}$ May, $15^{\text {th }}$ May and $31^{\text {th }}$ May and three phosphorus fertilization rates, i.e. $0,37.2$ and $74.4 \mathrm{~kg} \mathrm{P}_{2} \mathrm{O}_{5} / \mathrm{ha}$ on the performance of three soybean (Glycine max (L.) Merrl) cultivars i.e. Crawford, Giza 22 and Giza 111 on growth, yield and seed quality. The tallest plants, the thick stem, highest branches number/plant, pods number/plant, seed number/pod, weight of 1000 seed and seed yield/ha were recorded from sown early on first May in the both seasons. The tallest plants, the thick stems and highest number of branches/plant were recorded from sown Crawford cultivar. Whereas maximum number of pods/plant and number of seed/pod were found from sown Giza 111 cultivar in the both seasons. Increasing phosphorous fertilizer rates significantly increased all studied cultivars of seed yield and yield components. Tallest plant, the thick stem, the highest branches number/plant, pods number/plant, seed number/pod, weight of 1000 seed and seed yield/ha were produced from phosphorous fertilizer at a rate of $74.4 \mathrm{~kg} \mathrm{P}_{2} \mathrm{O}_{5} / \mathrm{ha}$ in the first and second seasons, respectively.
\end{abstract}

Keywords- Soybean cultivars, planting dates, phosphorus fertilization rates, seed yield and yield components.

\section{INTRODUCTION}

Soybean (Glycine max L. Merrill) considered one of the greatest essential oil and protein legume crops as its high quality protein, 85 percent cholesterol free oil content (Malik et al., 2007). Soybean has gained increased attention in Egypt agriculture, because there is a great shortage source of vegetable oil. Sowing date is one of the major factors that influence growth and yield of legumes and positively correlates phonological phase of the environmental factors. The rationale for planting early is to avoid the high temperature of July and August for most flowering and seed filling (Heatherly, 2005). Decreases in seed yield produced when planting delayed until after the critical dates in late May and early June (De Bruin and Pedersen, 2008 and Egli and Cornelius, 2009). Maximum oil content obtained when planting in May, and oil content decreased as planting was delayed further (Muhammad et al., 2009).Seed yield/ha increased by $19.7 \%$ when sown on $5^{\text {th }}$ May compared with those sowed on $5^{\text {th }}$ June and increased seed yield by $17.9 \%$ paralleled with those sowed on $20^{\text {th }}$ April, and augmented seed yield by $10.3 \%$ paralleled with those sowed on $20^{\text {th }}$ May (Kandil et al., 2012). The best sowing date on mid-June, but sowing lately on June avoids due to a reduction in yield and yield components (Yagoub and Hamed, 2013). The greatest seed yield obtained with an early sowing in mid-February and midMarch compared to late-April planting dates (Grichar and Biles, 2014). Significantly, higher yields obtained for earlier planting dates and yield decreased as planting delayed (Hankinson, 2015).Sowing soybean on July maximized seed yield and yield components (Nwofia et al., 2016).

Soybean cultivars differ markedly to dark period required to induce flowering. New genotypes are an important source to enhance and increase the commercial varieties productivity (Dong et al., 2001). Significant variances among studied genotypes for measurements viz., number of days to $50 \%$ flowering, plant height, pods number/plant, branches number/plant, 100-seed weight and grain yield (Malik et al., 2007).Sown cv. Giza 21 exceeded H-32 line by $16.63 \%$ and H-30 line by $14.6 \%$, Giza 22 cv. by $13.7 \%, \mathrm{H}-2 \mathrm{~L} 12$ line by $6.5 \%$ and Giza111cv.by $5.3 \%$ of seed yield/ha (Kandil et al., 2012).The TGx1485-1D cultivar recorded maximized seed yield per unite land area,while the TGx1987-10F cultivar produced the lowest (Nwofia et al., 2016).Pods number and seed per plant differed among cultivars, and 
the cultivar "BRS 284" showed the best results (Junior et al., 2017).

Low phosphorus in soil is a major constraint for soybean growth and seed production. Increase phosphorus fertilization from 75 to $375 \mathrm{~kg} \mathrm{P}_{2} \mathrm{O}_{5} / \mathrm{ha}$, soybean yield increased up to $20 \%$ compared with the control level. Further $\mathrm{P}$ fertilization increase up to $975 \mathrm{~kg} \mathrm{P}_{2} \mathrm{O}_{5} / \mathrm{ha}$ did not increase seed yield, but it has influence to seed quality (Antunović et al., 2012). To improve growth and development of plants due to supply phosphorus increased with the supply of assimilates to the seed, which finally gained more weight (Devi et al., 2012). Phosphorus supplement at the rate of $60 \mathrm{~kg} \mathrm{P}_{2} \mathrm{O}_{5} / \mathrm{ha}$ produced the tallest plants and increased weight of 100 seeds and seed yield/ha(Matusso and Cabo, 2015).Phosphorus application at a rate of $60 \mathrm{~kg} / \mathrm{ha} P$ produced the highest seed yield/ha and $60 \mathrm{~kg} / \mathrm{ha} \mathrm{P}$ recommended for greatest soybean production per unite area(Maga et al., 2017).

Sowing Giza-21, Giza-111, H-2 L12 and H-32 genotypes on $5^{\text {th }}$ May or $20^{\text {th }}$ May maximized seed yield(Kandil et al., 2012). The interaction between Genotype $x$ environment played a significant role and given most genetic materials adapted to a range of environments. TGX 1910-14F and TGX1440-1E cultivars were stable under different phosphorus rates (Ikeogu and Nwofia, 2013). The higher pods numberper plant, seeds number of pods on the main stem and greatest seed yield/ha produced by April 30 and Sahar cultivar (Sadeghi and Niyaki, 2013). Soybean genotypes on early sown createdmore seed yield and quality as related to later planting dates. The highestpods number/plant and seeds number/plant recorded from $28^{\text {th }}$ January and Faisal cultivar (Rehman et al., 2014). Higher amount of seed protein content produced from middle and late sowing dates. The seed yield decreased with a delay of sowing dates(Junior et al., 2017).Sowing on $21^{\text {th }}$ March, Williams-82 cultivar and $14^{\text {th }}$ March, Williams-82cultivar recorded the largestpods number per plant and the number of seeds/plant (Shah et al., 2017).

Early planting of Pan 520RR and Highveld Top cultivars with increasing phosphorus rates up to maximized seed yield/ha (Mabapa et al., 2010).Consequently, the goals of the study were to check growth, yield and yield component responses of some soybean genotypes to sowing date and phosphorus fertilizer levels.

\section{MATERIALS AND METHODS}

\subsection{Research time and site:}

Three separate field experiments carried out in the extensive field for each season at Mehalla El-Kobra, ElGahrbia district, Egypt during 2015 and 2016 seasons. Each experiment assigned in split plot design in RCBD with four replicates. The three separate experiments in each season include the sowing date at $1^{\text {th }}$ May, $15^{\text {th }}$ May and $31^{\text {th }}$ May. The three soybean (Glycine max (L.) Merrl) cultivars i.e. Crawford, Giza 22 and Giza 111 assigned in main-plots. Three phosphorus fertilization rates, i.e. $0,37.2$ and $74.4 \mathrm{~kg} \mathrm{P}_{2} \mathrm{O}_{5} /$ ha assigned in subplots. Then combined analysis done between sowing dates to get the main effect of planting dates and interaction between cultivars, phosphorus fertilization rates and planting dates. Each plot contained of five rows, $60 \mathrm{~cm}$ apart and four $\mathrm{m}$ long. The preceding crop was wheat. The analyses of chemical and physical properties of the experimental soil ( 0 to $30 \mathrm{~cm}$ depth) carried out according to the methods reported by Page et al. (1982). The soil was loamy clay in texture, the $\mathrm{pH}$ was $7.9,7.6$, organic matter was $4.8,4.9 \%, 7.7,7.5$, E.C. $\mathrm{dS} / \mathrm{m}^{-1}$, available nitrogen was 15.7 and $16.3 \mathrm{ppm}$ and available phosphorus was 39.6 and 39.1 ppm of both seasons, respectively. Soybean seeds of the studied cultivars obtained from the Field Crops Research Institute, A. R. C., and Giza, Egypt. Seeds of studied varieties infected by specific rhizobia. After plotting and before the planting, sulfate of potassium $\left(48 \% \mathrm{~K}_{2} \mathrm{O}\right)$ at a rate of $120 \mathrm{~kg} / \mathrm{ha}$ and phosphorus fertilizers of the form calcium superphosphate $\left(\begin{array}{llll}15.5 & \% & \mathrm{P}_{2} \mathrm{O}_{5}\end{array}\right)$ at above rates supplied to experimental plots. Nitrogen at $36 \mathrm{~kg} \mathrm{~N} / \mathrm{ha}$ of ammonium nitrate $(33.5 \% \mathrm{~N})$ added before the first irrigation for each plot..

\subsection{Studied Characters:}

Ten guarded plants randomly taken from each plot to measure plant height $(\mathrm{cm})$, stem diameter, branches number/plant, pods number/plant, weight of 1000-seed $(\mathrm{g})$ and seed weight/plant $(\mathrm{g})$. The two inner of the central area harvested to find seed yield $/ \mathrm{m}^{2}$ in each plot and then calculated in $\mathrm{kg}$ per hectare.

\subsection{Experimental analysis:}

The analysis of data collected and statistically by the analysis of variance technique using the MSTAT-C statistical package programmed as described by a procedure of Gomez and Gomez (1991). Lest significant differences test (LSD) at 5 and $1 \%$ level of probability was used to compare between treatment means according to Snedecor and Cochran (1980).Combined analysis between planting dates done according to Waller and Duncan (1969).

\section{RESULTS AND DISCUSSION}

\subsection{Planting dates effects:}

Means of plant height $(\mathrm{cm})$, stem diameter $(\mathrm{cm})$, seed number/pod, and seed yield/ha $(\mathrm{kg})$ as influenced by sowing date, in both seasons, except, branches number/plant, pods number/plant, weight of 1000 seed (g) insignificantly influenced only in the second one as 
exposed in Tables (1 and 2). The tallest plants (125.5, $136.9 \mathrm{~cm})$, the thick stems $(1.02,1.22 \mathrm{~cm})$, highest number of branches/plant $(5.1,6.1)$, number of pods/plant $(123.3,135.0)$, number of seed/pod $(2.70,2.72), 1000$ seed weight(203.30, $204.4 \mathrm{~g})$ and seed yield/ha (3017.5, 30.49.7 kg/ha)were recorded from sown early on first May in the first and second seasons, respectively. However, the lowest values rom sown lately on end May. Decreases in seed yield produced when planting delayed until after the critical dates in late May and early June (De Bruin and Pedersen, 2008 and Egli and Cornelius, 2009). The highest percentages of oil was obtained when planting in May, and oil content decreased as planting delayed further (Muhammad et al., 2009). Grichar and Biles (2014), Hankinson (2015) and Nwofia et al. (2016) recorded similar conclusions.

\subsection{Cultivars performance:}

Averages of plant height $(\mathrm{cm})$, branches number/plant and pods number/plant significantly affected by soybean studied cultivars, in both seasons. However, stem diameter $(\mathrm{cm})$ in the second season and number of seed/pod, in the first one significantly affected, weight of 1000 seed ( $\mathrm{g}$ ) and seed yield in $\mathrm{kg} / \mathrm{ha}$ in both seasons insignificantly influenced only in the second one as revealed in Tables (1 and 2).The tallest plants (126.1, $136.5 \mathrm{~cm})$, the thick stems $(0.98,1.26 \mathrm{~cm})$ and highest number of branches/plant 4.6, 6.3) were recorded from sown Crawford cultivar. However, the highest number of pods/plant $(100.7,146.9)$ and number of seed/pod $(2.77$, 2.76) were obtained from sown Giza 111 cultivar in both seasons, respectively. Significant variances among studied genotypes for measurements viz., number of days to $50 \%$ flowering, plant height, pods number/plant, branches number/plant, 100-seed weight and grain yield (Malik et al., 2007).The TGx1485-1D cultivar recorded maximized seed yield per unite land area, while the TGx1987-10F cultivar produced the lowest (Nwofia et al., 2016).Pods number and seed per plant varied between genotypes, and the cv. BRS 284 showed the best results (Junior et al., 2017).

\subsection{Phosphorus fertilizer rate effects:}

Means of plant height $(\mathrm{cm})$, stem diameter $(\mathrm{cm})$, branches number/plant, pods number/plant, weight of 1000 seed (g) and seed yield/ha $(\mathrm{kg})$ significantly affected by phosphorous fertilizer rates in both seasons, except, number of seed/pod insignificantly influenced only in the second one as exposed in Tables (1 and 2). Increasing phosphorous fertilizer rates significantly increased all studied cultivars of seed yield and yield components. The tallest plants $(128.7,136.5 \mathrm{~cm})$, the thick stem $(0.79,1.24$ $\mathrm{cm})$, the highest number of branches/plant $(5.3,6.2)$, number of pods/plant $(110.7,146.8)$, number of seed/pod (2.79, 2.75), 1000 seed weight $(204.8,211.3 \mathrm{~g})$ and seed yield $(2936.9,2988.7 \mathrm{~kg} / \mathrm{ha})$ were produced from phosphorous fertilizer at a rate of $74.4 \mathrm{~kg} \mathrm{P}_{2} \mathrm{O}_{5} /$ ha.Low phosphorus in soil is a major constraint for soybean growth and seed production. Increase phosphorus fertilization from 75 to $375 \mathrm{~kg} \mathrm{P}_{2} \mathrm{O}_{5} / \mathrm{ha}$, soybean yield increased up to $20 \%$ compared with the control level. Further $\mathrm{P}$ fertilization increase up to $975 \mathrm{~kg} \mathrm{P}_{2} \mathrm{O}_{5} / \mathrm{ha}$ did not increase seed yield, but it has influence to seed quality (Antunović et al., 2012). To improve growth and development of plants due to supply phosphorus increased with the supply of assimilates to the seed, which finally gained more weight (Devi et al., 2012). Similarly, results in good covenant with those reported by Kamara et al.(2007).Matusso and Cabo (2015) and Maga et al. (2017).

\subsection{Interaction Effects:}

3.4.1. Interaction between sowing dates and soybean cultivars:

Averages ofplant height $(\mathrm{cm})$, number of branches/plant, number of seed/pod andseed yield/ha $(\mathrm{kg})$ significantly affected by the interaction between sowing date and studied soybean cultivars in both seasons, but, insignificantly affected stem diameter $(\mathrm{cm})$, pods number/plant and weight of 1000 seed $(\mathrm{g})$. The results showed that tallest plants $(132.1,140.7 \mathrm{~cm})$ and number of branches/plant $(5.9,7.5)$ were obtained from sown Crawford cultivar in first May in both seasons as shown in Figs 1 and 2. While the lowest values were produced from sown Giza 111 cultivar lately on end May. Moreover, the highest number of seed/pod $(2.83,2.87)$ and seed yield/ha $(3117.1,3142.0 \mathrm{~kg} / \mathrm{ha})$ were produced from sown Giza 111 cultivar on first May in both seasons as shown in Figs. 3 and 4.Whilst, the lowest values were produced from sown Giza 22 cultivar on mid-May. Decreases in seed yield produced when planting delayed until after the critical dates in late May and early June (De Bruin and Pedersen, 2008 and Egli and Cornelius, 2009). 
Table.1: Average of plant height (cm), stem diameter $(\mathrm{cm})$, branches number/plant and pods number/plant as influenced by date of sowing, soybean cultivars and phosphate fertilization rates in both seasons.

\begin{tabular}{|c|c|c|c|c|c|c|c|c|}
\hline \multirow[t]{2}{*}{$\begin{array}{c}\text { Characters } \\
\text { Treatments }\end{array}$} & \multicolumn{2}{|c|}{$\begin{array}{l}\text { Plant height } \\
\quad(\mathrm{cm})\end{array}$} & \multicolumn{2}{|c|}{$\begin{array}{l}\text { Stem diameter } \\
(\mathrm{cm})\end{array}$} & \multicolumn{2}{|c|}{$\begin{array}{c}\text { Branches } \\
\text { number/plant }\end{array}$} & \multicolumn{2}{|c|}{ Pods number/plant } \\
\hline & 2014 & 2015 & 2014 & 2015 & 2014 & 2015 & 2014 & 2015 \\
\hline \multicolumn{9}{|l|}{ A-Sowing date: } \\
\hline 1 May & 125.5 & 136.9 & 1.02 & 1.22 & 5.1 & 6.1 & 123.3 & 135.0 \\
\hline 15 May & 123.6 & 127.9 & 0.91 & 1.24 & 5.0 & 5.9 & 90.4 & 129.6 \\
\hline 31 May & 123.7 & 131.1 & 0.85 & 1.21 & 4.4 & 6.6 & 78.0 & 131.6 \\
\hline F. test & $*$ & $*$ & $*$ & $*$ & $*$ & N.S & $*$ & $*$ \\
\hline LSD at $5 \%$ & 3.6 & 6.6 & 0.07 & 0.13 & 0.1 & --- & 6.6 & 11.2 \\
\hline \multicolumn{9}{|c|}{ B-Soybean Cultivars: } \\
\hline Giza 111 & 123.5 & 127.6 & 0.93 & 1.17 & 5.3 & 6.1 & 100.7 & 146.9 \\
\hline Giza 22 & 123.3 & 131.8 & 0.92 & 1.20 & 4.5 & 6.2 & 94.0 & 142.7 \\
\hline Crawford & 126.1 & 136.5 & 0.98 & 1.26 & 4.6 & 6.3 & 97.0 & 106.5 \\
\hline F. test & $*$ & * & $*$ & N.S & $*$ & $*$ & N.S & $*$ \\
\hline LSD at $5 \%$ & 3.6 & 6.7 & 0.02 & -- & 0.1 & 0.1 & -- & 11.2 \\
\hline \multicolumn{9}{|c|}{ C-Phosphorus fertilization: } \\
\hline $0 \mathrm{~kg} \mathrm{P}_{2} \mathrm{O}_{5} / \mathrm{ha}$ & 119.3 & 127.1 & 0.87 & 1.20 & 4.3 & 5.1 & 81.1 & 118.0 \\
\hline $37.2 \mathrm{~kg} \mathrm{P}_{2} \mathrm{O}_{5} / \mathrm{ha}$ & 124.9 & 132.4 & 0.94 & 1.22 & 4.8 & 6.4 & 99.9 & 131.2 \\
\hline $74.4 \mathrm{~kg} \mathrm{P}_{2} \mathrm{O}_{5} / \mathrm{ha}$ & 128.7 & 136.5 & 0.97 & 1.24 & 5.3 & 6.2 & 110.7 & 146.8 \\
\hline F. test & $*$ & $*$ & $*$ & $*$ & $*$ & * & $*$ & $*$ \\
\hline LSD at $5 \%$ & 2.9 & 5.7 & 0.06 & 0.02 & 0.2 & 0.2 & 6.3 & 10.4 \\
\hline
\end{tabular}

Table.2: Average of seed number/pod, of 1000 seed weight and seed yield in $\mathrm{kg} / \mathrm{ha}$ as influenced by sowing date, studied soybean cultivars and phosphorus fertilization rates in both seasons.

\begin{tabular}{|c|c|c|c|c|c|c|}
\hline \multirow{2}{*}{$\begin{array}{l}\text { Characters } \\
\text { Treatments }\end{array}$} & \multicolumn{2}{|c|}{ Seed number/pod } & \multicolumn{2}{|c|}{1000 seed weight } & \multicolumn{2}{|c|}{ Seed yieldin $\mathrm{kg} / \mathrm{ha}$} \\
\hline & 2014 & 2015 & 2014 & 2015 & 2014 & 2015 \\
\hline \multicolumn{7}{|l|}{ A-Sowing date: } \\
\hline 1 May & 2.70 & 2.72 & 203.0 & 204.4 & 3017.5 & 3049.6 \\
\hline 15 May & 2.63 & 2.63 & 200.9 & 204.4 & 2333.0 & 2369.7 \\
\hline 31 May & 2.87 & 2.70 & 185.3 & 198.5 & 2116.0 & 2139. \\
\hline F. test & * & N.S & * & N.S & $*$ & * \\
\hline LSD at $5 \%$ & 0.16 & --- & 10.9 & --- & 32.4 & 36.1 \\
\hline \multicolumn{7}{|l|}{ B-Soybean Cultivars: } \\
\hline Giza 111 & 2.77 & 2.76 & 202.5 & 206.7 & 2516.8 & 2553.6 \\
\hline Giza 22 & 2.68 & 2.57 & 191.6 & 199.8 & 2460.9 & 2502.0 \\
\hline Crawford & 2.74 & 2.72 & 195.1 & 200.8 & 2489.0 & 2503.6 \\
\hline F. test & $*$ & $*$ & N.S & N.S & N.S & N.S \\
\hline LSD at $5 \%$ & 0.16 & 0.13 & --- & --- & --- & --- \\
\hline \multicolumn{7}{|c|}{ C-Phosphorus fertilization: } \\
\hline $0 \mathrm{~kg} \mathrm{P}_{2} \mathrm{O}_{5} / \mathrm{ha}$ & 2.74 & 2.64 & 191.5 & 195.6 & 2088.0 & 2085.3 \\
\hline $37.2 \mathrm{~kg} \mathrm{P}_{2} \mathrm{O}_{5} / \mathrm{ha}$ & 2.66 & 2.66 & 193.0 & 200.4 & 2442.2 & 2485.2 \\
\hline $74.4 \mathrm{~kg} \mathrm{P}_{2} \mathrm{O}_{5} / \mathrm{ha}$ & 2.79 & 2.75 & 204.8 & 211.3 & 2936.4 & 2988.7 \\
\hline F. test & ** & N.S & $*$ & $*$ & $*$ & $*$ \\
\hline LSD at $5 \%$ & 0.25 & --- & 8.0 & 5.3 & 64.2 & 40.1 \\
\hline
\end{tabular}




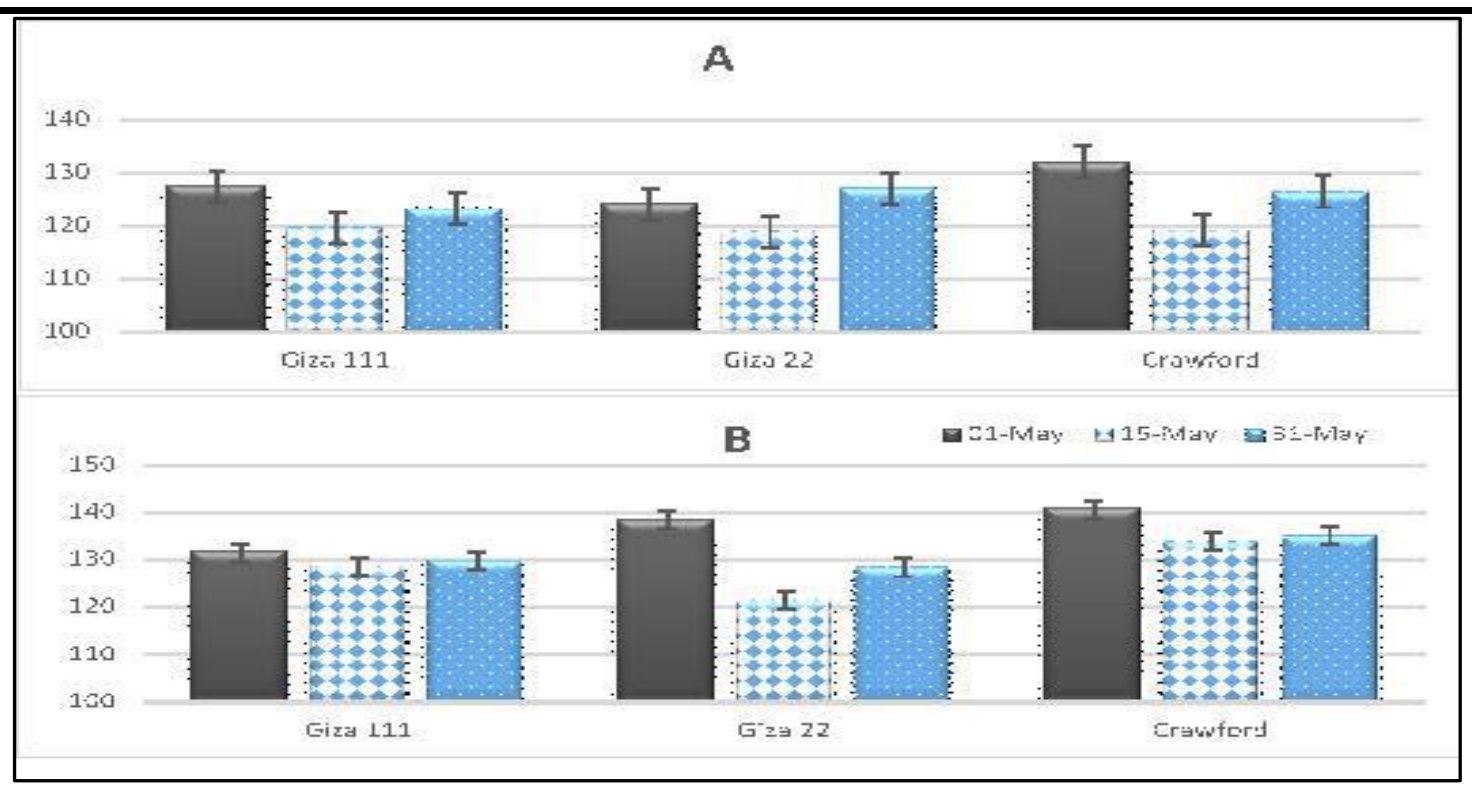

Fig.1: Average of plant height $(\mathrm{cm})$ as influenced by the interactiveamong soybean cultivars and sowing date during two season (A) 2014 and (B) 2015 seasons.

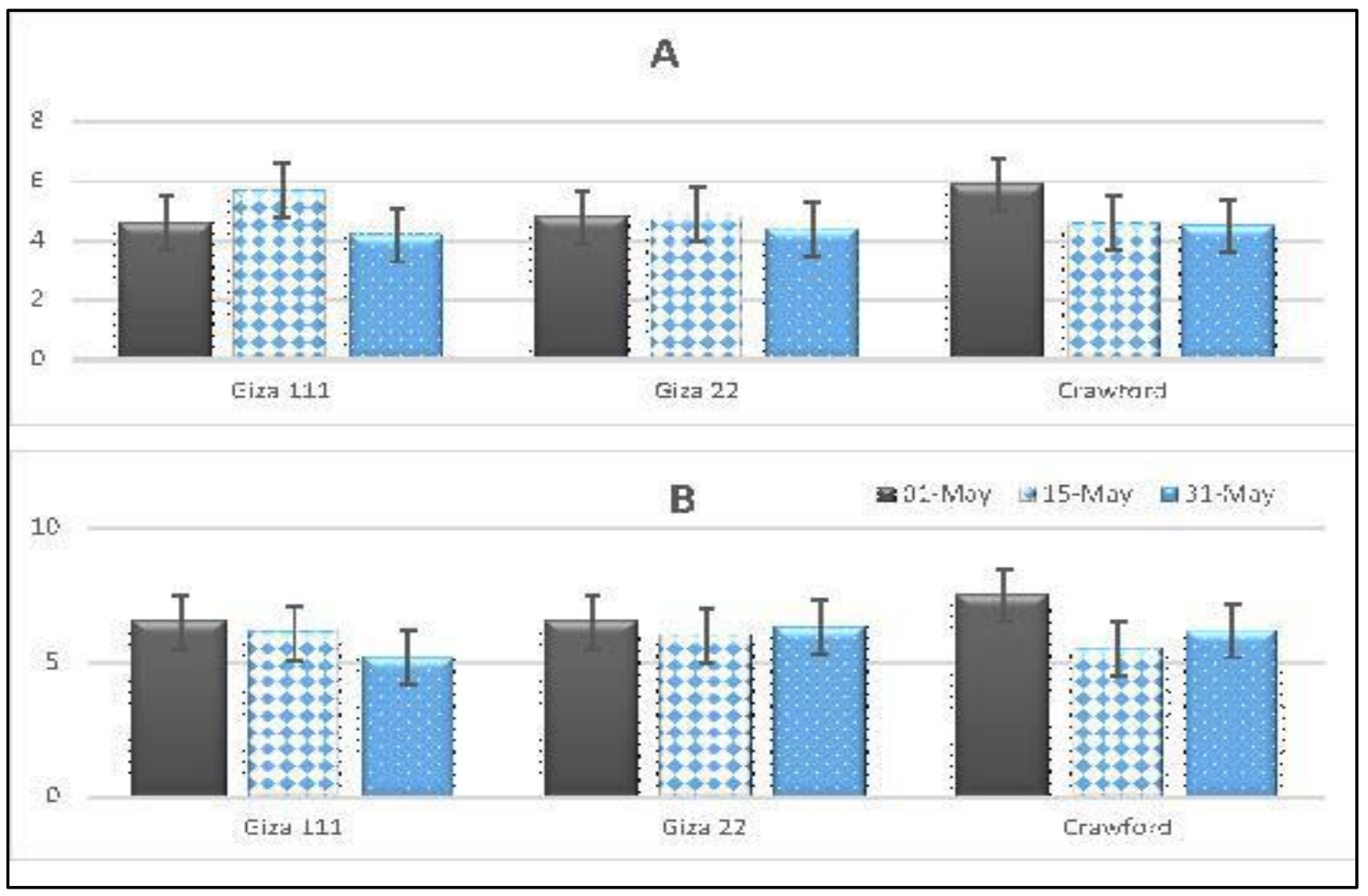

Fig.2: Average of number of branches/plant as affected by interaction between soybean cultivars and sowing date during 2014 and 2015 seasons. 


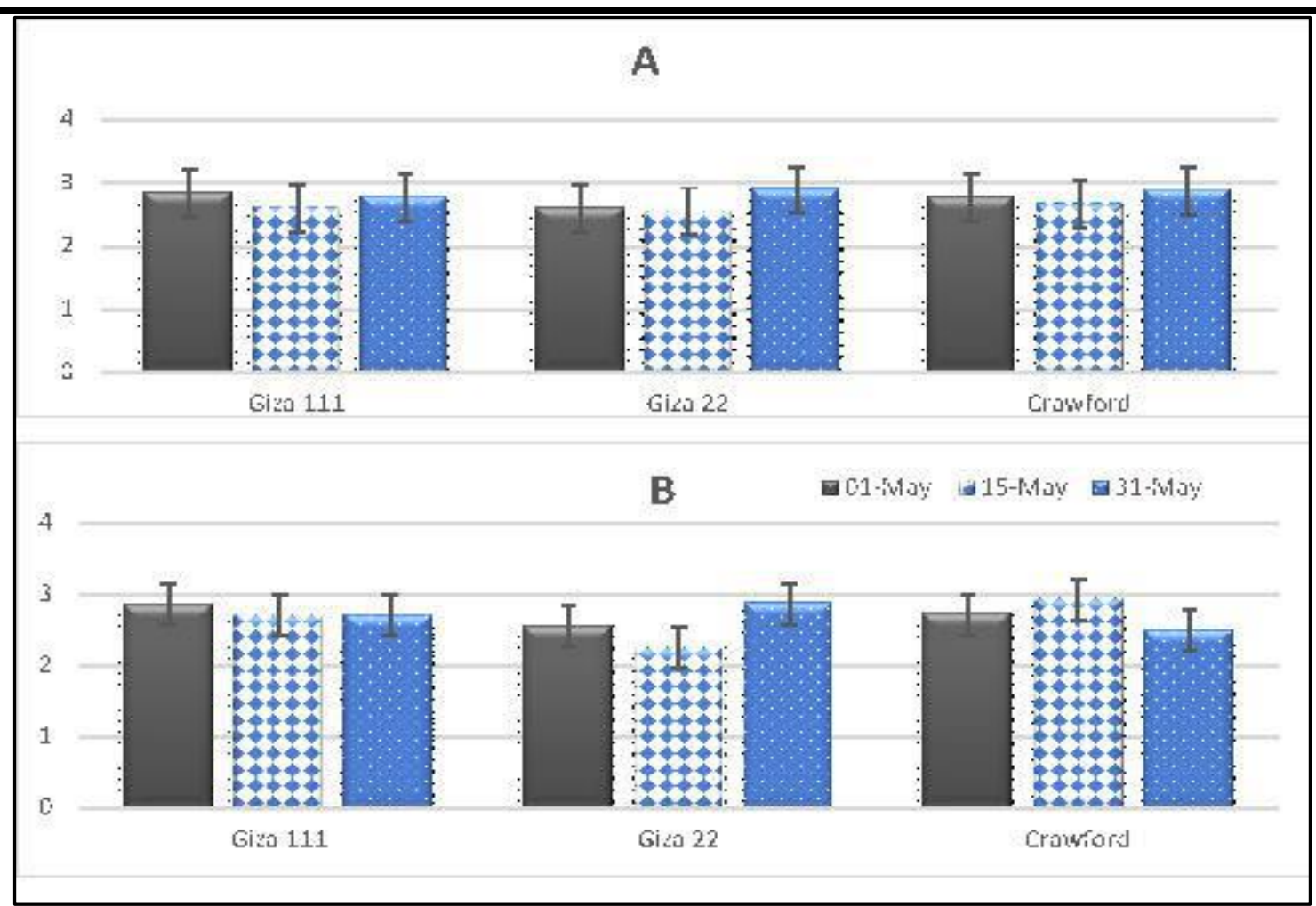

Fig.3: Average of number of seed/pod as affected by interaction between soybean cultivars and sowing date during 2014 and 2015 seasons.

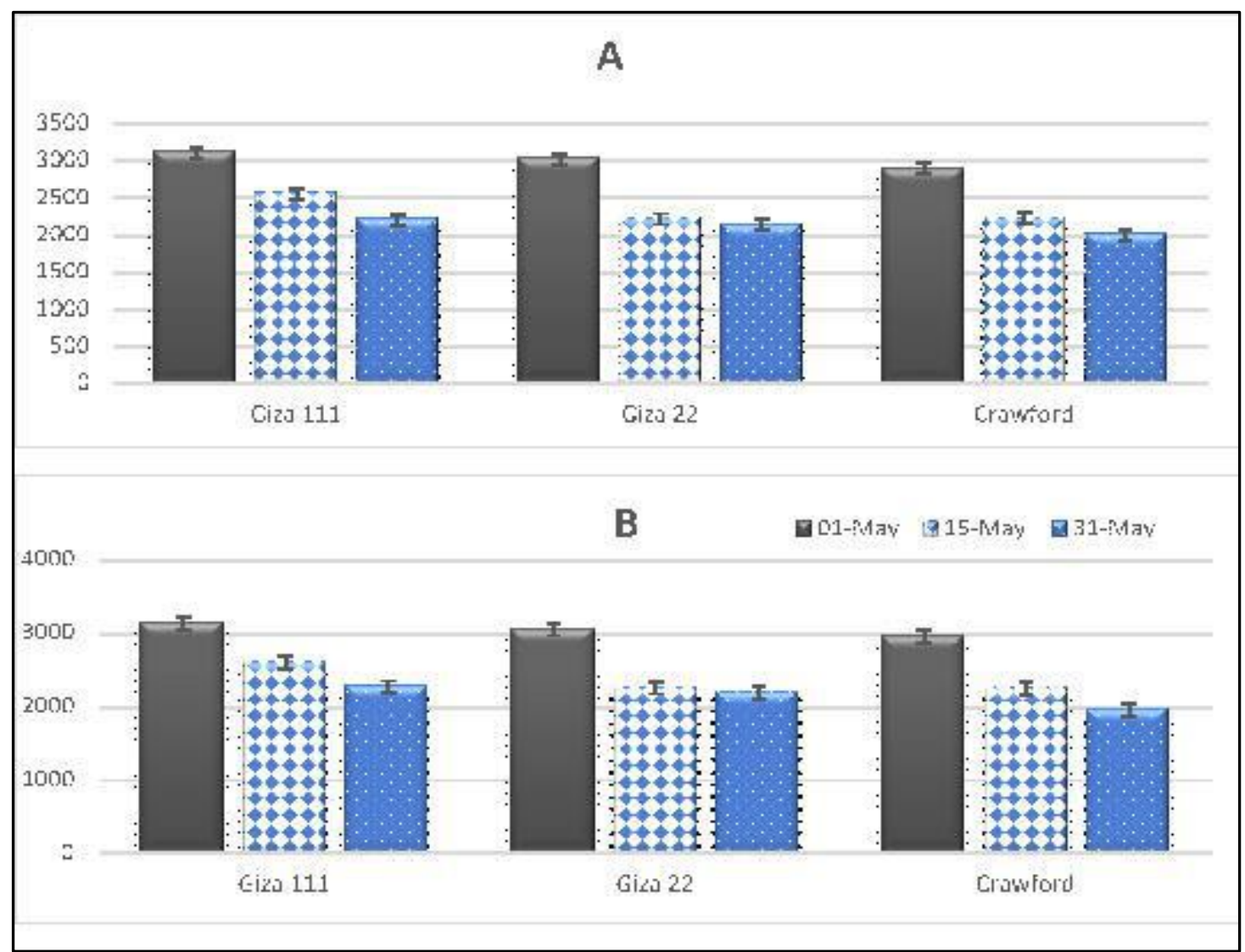

Fig.4: Average of seed yield/ha $(\mathrm{kg})$ as affected by interaction between soybean cultivars and sowing date during 2014 and 2015 seasons. 


\subsubsection{Interaction between sowing dates and} phosphorus fertilizer rates:

Mean of branches number/plant, pods number/plant, seed number/pod and seed yield/ha (kg)significantly affected by the interaction between sowing date and phosphorus fertilizer rates, but, plant height $(\mathrm{cm})$, stem diameter $(\mathrm{cm})$ and 1000 seed weight $(\mathrm{g})$ insignificantly affected in both seasons. The highest number of branches/plant $(5.5,6.7)$, number of seed/pod $(138.2,158.0)$, number of seed/pod $(2.88,2.83)$ and seed yield $\mathrm{kg} / \mathrm{ha}(3511.2,3546.2 \mathrm{~kg} / \mathrm{ha})$ were obtained from sown early in first May and phosphorus fertilizer at a rate of $74.4 \mathrm{~kg} \mathrm{P}_{2} \mathrm{O}_{5} / \mathrm{ha}$ in both seasons as shown in Figs. 5, 6, 7 and 8. However, the lowest values were produced from sown on end May and without phosphorus fertilization. To improve growth and development of plants due to supply phosphorus increased with the supply of assimilates to the seed, which finally gained more weight(Devi et al., 2012). Phosphorus application at the rate of $60 \mathrm{~kg} / \mathrm{ha} P$ produced the highest seed yield/ha and $60 \mathrm{~kg} / \mathrm{ha} \mathrm{P}$ recommended for greatest soybean production per unite area(Maga et al., 2017).

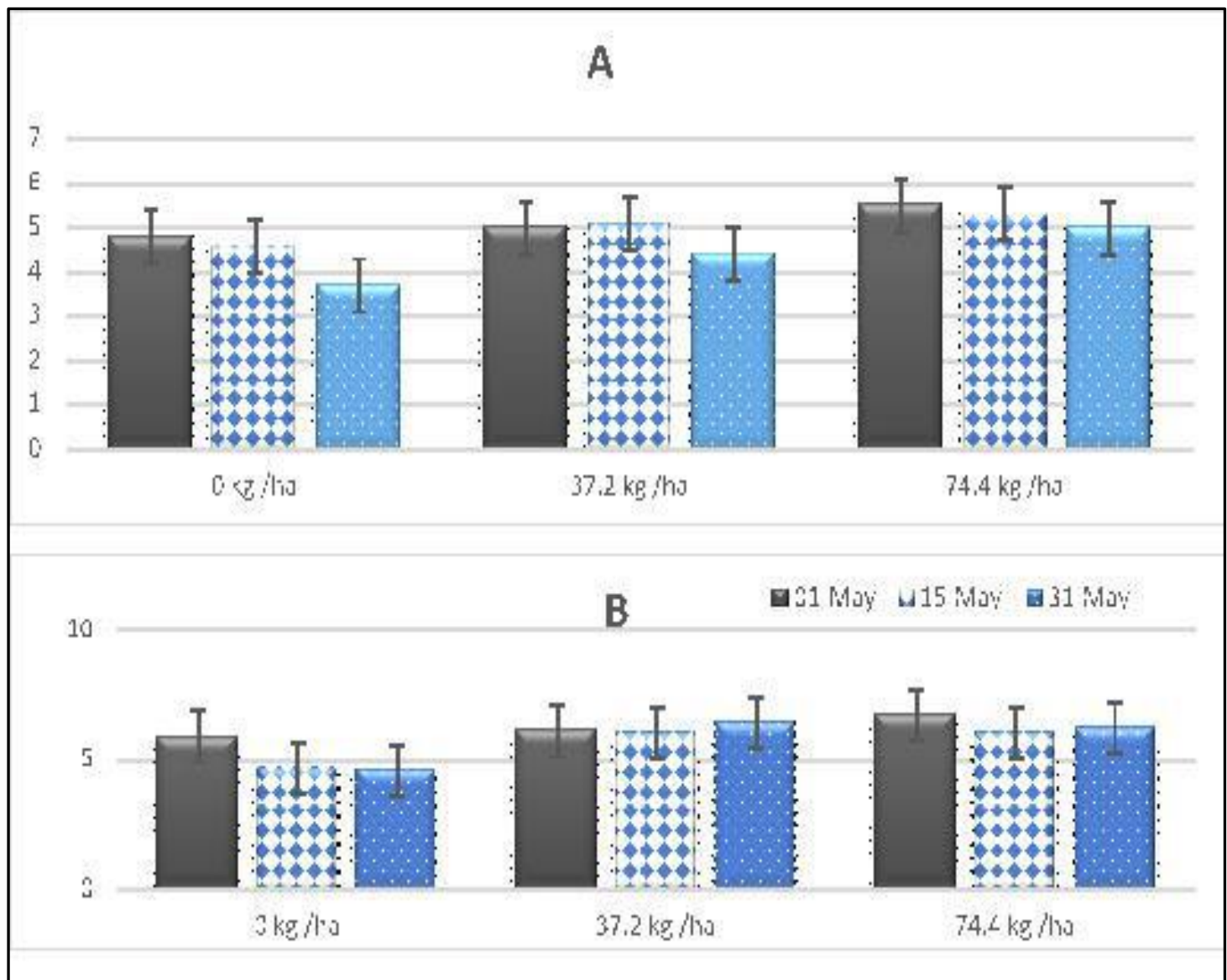

Fig.5: Average of number of branches/plant as influenced by interaction between phosphate fertilization and sowing date during 2014 and 2015 seasons. 


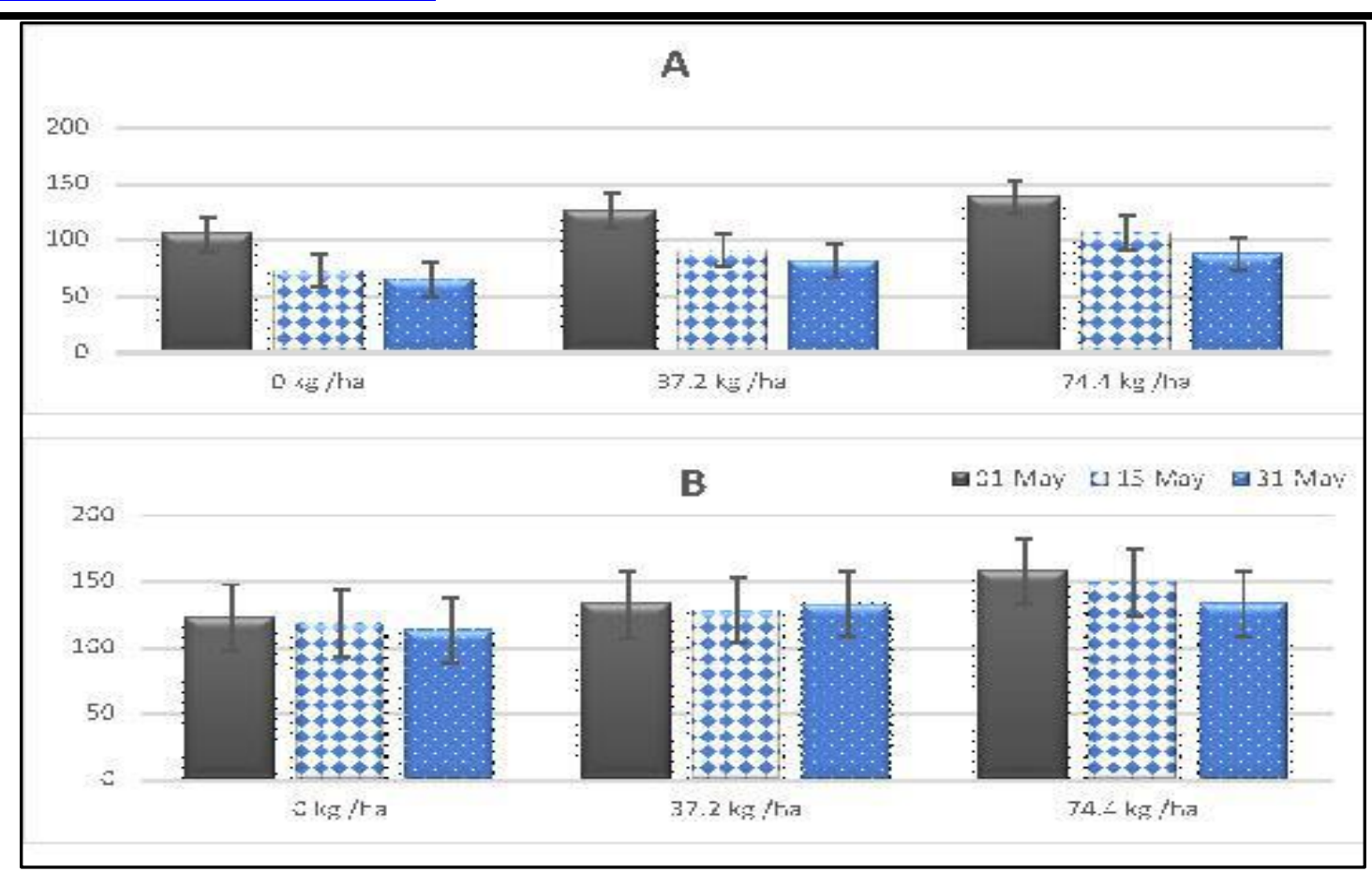

Fig.6: Average of number of pods/plant as influenced by interaction between phosphate fertilization and sowing date during 2014 and 2015 seasons.

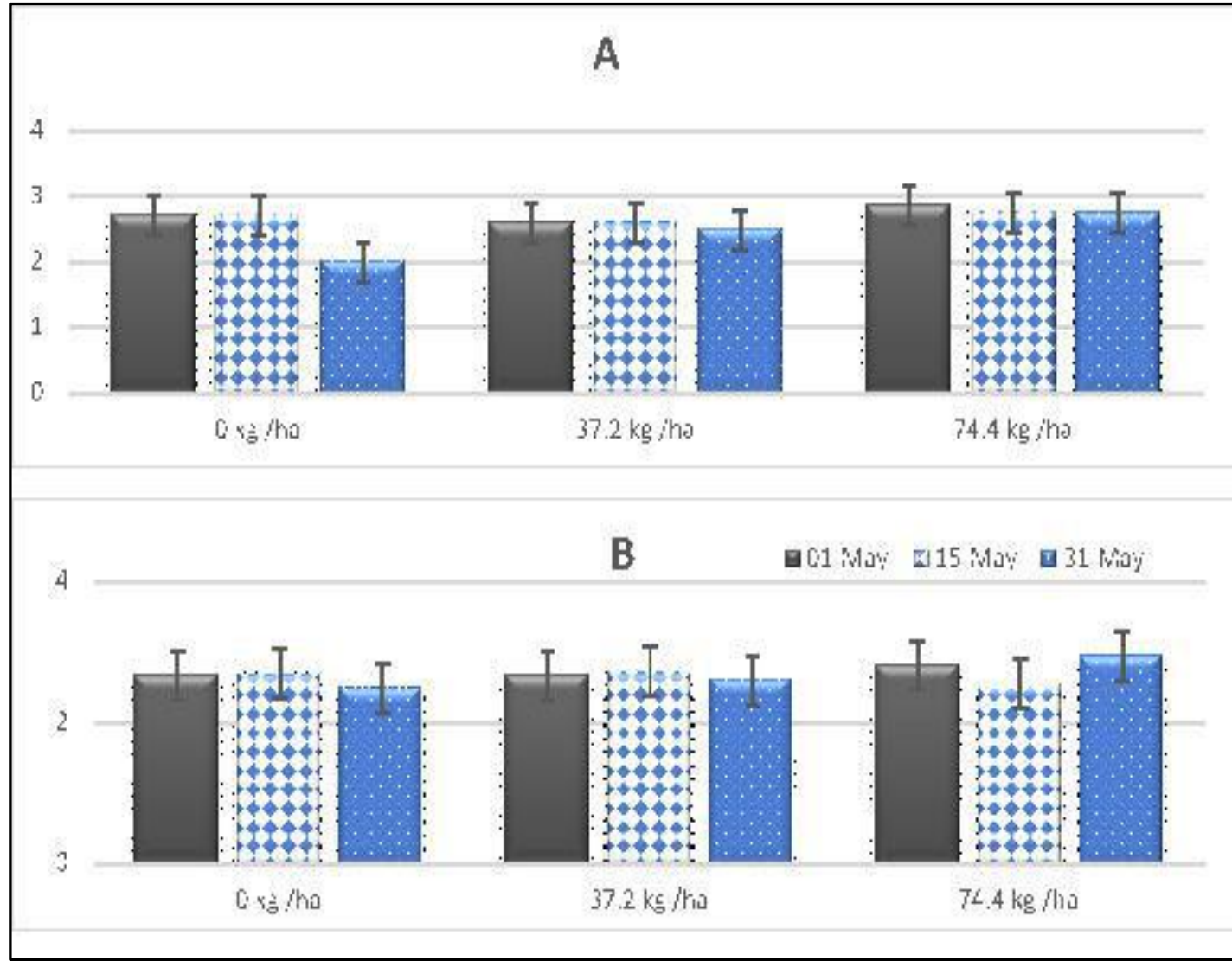

Fig.7: Average of number of seed/pod as affected by interaction between phosphate fertilization and sowing date during 2014 and 2015 seasons.

3.4.3. Interaction between soybean cultivars and phosphorus fertilizer rates:

Averages of 1000 seed weight (g)significantly influenced by the interface between studied soybean cultivars and phosphorus fertilization rates in both seasons, but, insignificantly affected on plant height $(\mathrm{cm})$,stem diameter $(\mathrm{cm})$,number of branches/plant, number of pods/plant, number of seed/pod and seed yield $/ \mathrm{ha}(\mathrm{kg})$. 
The results clearly indicated that the heaviest 1000 seed weight $(205.7,213.7 \mathrm{~g})$ was produced from sown Giza 111 cultivar when fertilized by phosphorus fertilizer at a rate of $74.4 \mathrm{~kg} \mathrm{P}_{2} \mathrm{O}_{5} / \mathrm{ha}$ in both seasons as shown in Fig.9.However the less weight of 1000 seed was recorded from sown Crawford cultivar and without phosphorus fertilization.Sowing Giza-21, Giza-111, H-2 L12 and H-
32 genotypes on $5^{\text {th }}$ May or $20^{\text {th }}$ May maximized seed yield (Kandil et al., 2012). The interaction between Genotype $\mathrm{x}$ environment played a significant role and given most genetic materials adapted to a range of environments. TGX 1910-14F and TGX1440-1E cultivars were stable under different phosphorus rates (Ikeogu and Nwofia, 2013).

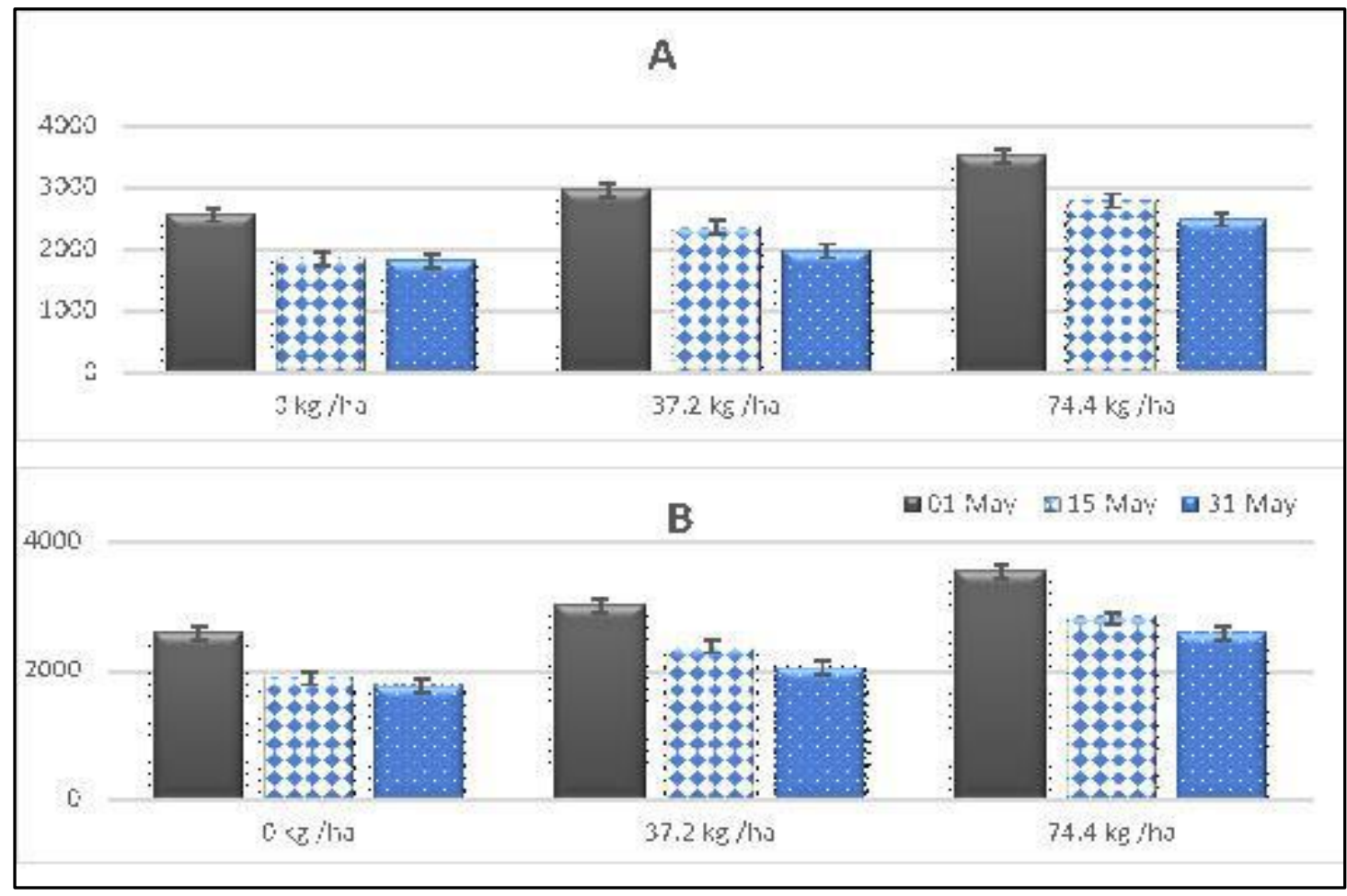

Fig.8: Average of seed yield/ha $(\mathrm{kg})$ as influenced by the interactive among phosphate fertilization and sowing date during 2014 and 2015 seasons.

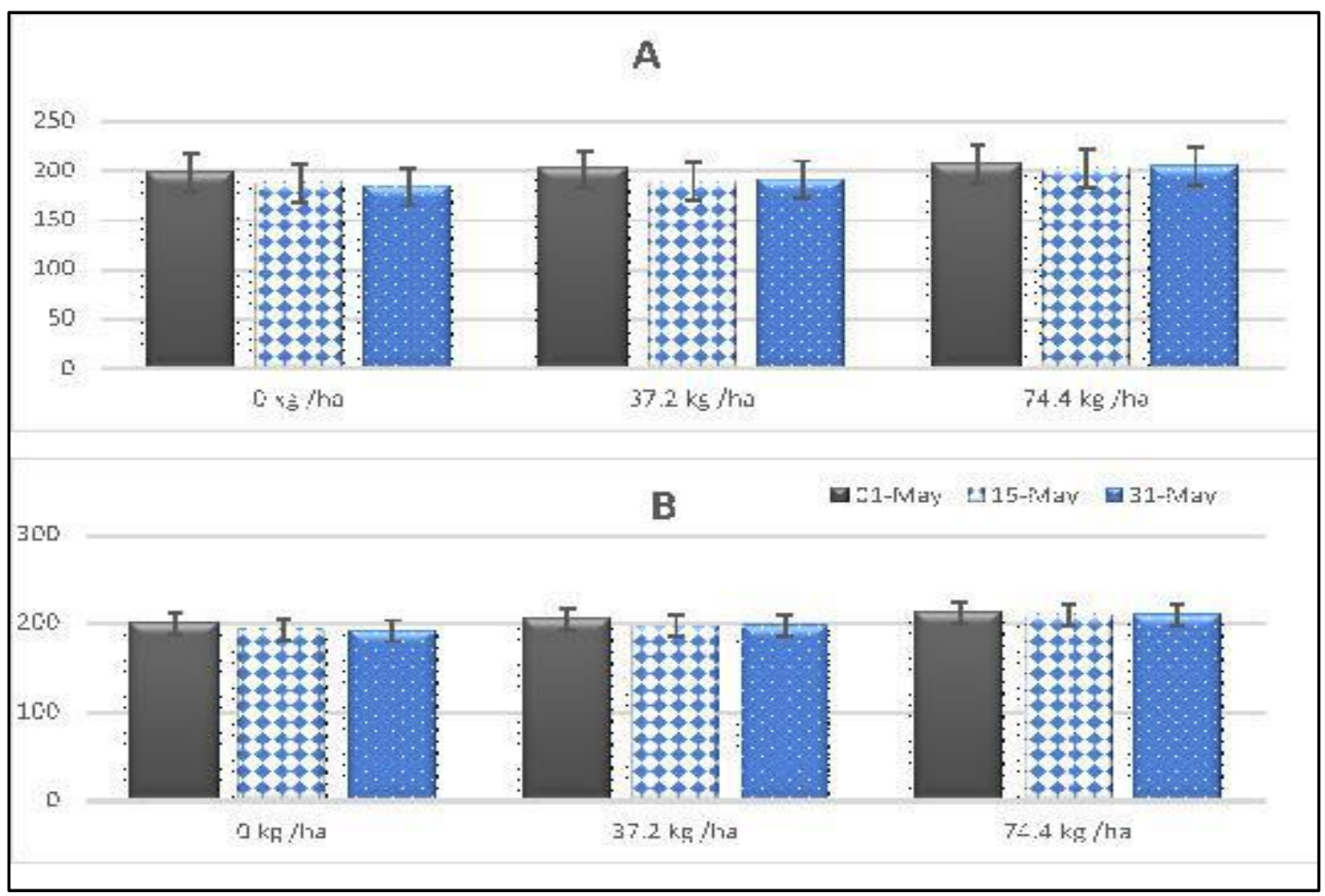

Fig.9: Average of 1000 Seed weight (gm).as affected by the interaction between phosphate fertilization and sowing date during 2014 and 2015 seasons. 
3.4.4. Interaction between sowing dates, soybean cultivars and phosphorus fertilizer rates:

Means of plant height $(\mathrm{cm})$,stem diameter $(\mathrm{cm})$,number of branches/plant,number of pods/plant, number of seed/pod,1000 seed weight (g)and seed yield/ha (kg)insignificantly affected by the interaction between sowing dates, soybean cultivars and phosphorus fertilizer rates.

\section{REFERENCES}

[1] Antunović, M., M. Rastija, A. Sudarić, I.Vargaand J.Jović2012. Response of Soybean to Phosphorus Fertilization under Drought Stress Conditions. $11^{\text {th }}$ Alps-Adria Scientific Workshop Smolenice, Slovakia, Pp: 117-120. DOI: 10.1556/Novenyterm.61.2012.Suppl.2

[2] De Bruin, J.L. and P. Pedersen 2008. Soybean Seed Yield Response to Planting Date and Seeding Rate in the Upper Midwest. Agronomy Journal, 100(3): 696-703.doi:10.2134/agronj14.0277

[3] Devi, K.N., L.N.K Singh,T.S. Devi, H.N. Devi, T.B. Singh, K.K. Singh and W.M. Singh2012. Response of Soybean (Glycine max (L.) Merrill) to Sources and Levels of Phosphorus. Journal of Agricultural $\begin{array}{lllll}\text { Science, } & 4 & (6): & 44\end{array}$ 53.DOI: http://dx.doi.org/10.5539/jas.v4n6p44

[4] Dong, Y.S., B.C. Zhuang, L.M. Zhao, H. Sun and M.Y. He. 2001. The genetic diversity of annualwild soybeans grown in China. Theor. Appl. Genet., 103(1): $\quad 98$ 103.http://www.cgris.net/973/The\%20genetic\%20di versity $\% 20 \mathrm{of} \% 20$ annual $\% 20$ wild $\% 20$ soybeans $\% 20$ grown\%20in\%20China.pdf

[5] Egli, D.B. and P.L. Cornelius 2009. A Regional Analysis of the Response of Soybean Yield to Planting Date. Agronomy Journal 101(2): 330335.doi:10.2134/agronj2008.0148

[6] Grichar, W. J.and S.P. Biles 2014. Response of Soybean to Early-Season Planting Dates along the Upper Texas Gulf Coast. International Journal of Agronomy Volume 2014, Article ID 252563, 7 pages, http://dx.doi.org/10.1155/2014/252563

[7] Hankinson, M.W. 2015. Planting Date and Starter Fertilizer Effects on Soybean Growth and Yield. M.Sc. Thesis, Ohio State University, USA. https://etd.ohiolink.edu/!etd.send_file?accession=OS $\underline{\mathrm{u} 1429734801 \& \text { disposition=inline }}$

[8] Heatherly, L. G. 2005. Midsouthern USA soybean yield affected bymaturity group and planting date. CropManagement, 4 (1): doi:10.1094/CM-20050418-01-RS

[9] Ikeogu, U. N. and Nwofia G. E. 2013. Yield parameters and stability of soybean [Glycine max.(L.) merril] as influenced by phosphorus fertilizer ratesin two ultisols. J. Plant Breed. Crop Sci., 5(4): 54-63. DOI: 10.5897/JPBCS12.014

[10] Kamara, A.Y., R. Abaidoo, J. Kwari and L. Omoigui2007. Influence of phosphorus application on growth and yield of soybean genotypes in the tropicalsavannas of northeast Nigeria, Archives of Agronomy and Soil Science, 53(5): 539552.http://dx.doi.org/10.1080/03650340701398452

[11] Kandil, A.A., A.E. Sharief, A.R. Morsy and A.I. Manar El-Sayed 2012.Performance of some Promising Genotypes of Soybean UnderDifferent Planting Dates Using Biplots Analysis. Journal of Basic \& Applied Sciences, 8:379-385. http://www.lifescienceglobal.com/images/Journal_ar ticles/JBASV8N2A22-Sharief.pdf

[12] Mabapa P. M., J. B. O. Ogola, J. J. O. Odhiambo, A. Whitbread andJ. Hargreaves 2010. Effect of phosphorus fertilizer rates on growth and yieldof three soybean (Glycine max) cultivars in LimpopoProvince. African Journal of Agricultural Research, 5(19): 2653-2660. http://www.academicjournals.org/article/article1380 963071_Mabapa\%20et\%20al.pdf

[13] Maga, T.J., T. S. Ter and K. J. Aorga 2017. Responses of soybean [glycine max (1.) Merrill] to phosphorusFertilizer timing and rates in Makurdi, Nigeria. International Journal of Scientific Research, 6(5):383-386.

https://www.worldwidejournals.com/internationaljournal-of-scientific-research(IJSR)/file.php?val=May_2017_1493736099_217. pdf

[14] Malik, M. F. A., M. Ashraf, A. S. Qureshi and A. Ghafoor 2007. Assessment of genetic variability, correlation and path analyses for yield and its components in soybean Pakistan Journal of Botany, 42(2):

971-976. https://pdfs.semanticscholar.org/17a7/426350783f03 e3c62267776261bc0106d760.pdf

[15] Materusse, M. J. M. and F. G. D. Cabo 2015.Response of Soybean [Glycine max (L.) Merrill] to Phosphorus Fertilizer Rates in Ferralsols. Acad. Res. J. Agri. Sci. Res. 3(10): 281-288.DOI: 10.14662/ARJASR2015.057

[16] Muhammad, A., S.K. Khalil, K.B. Marwat, and A.Z. Khan. 2009. Nutritional quality and production of soybean land races and improved varieties as affected by planting dates. Pak J Bot 41(2): 683689.http://www.pakbs.org/pjbot/PDFs/41(2)/PJB41( 2)683.pdf

[17] Nwofia, G.E., R.E. Edugbo and E.U. Mbah 2016. Interaction of Genotype $x$ Sowing Date on Yield and Associated Traits of Soybean [Glycine max (L.) Merrill] over Two Cropping Seasons in a Humid 
Agro-ecological Zone of South-Eastern Nigeria. The Journal of Agricultural Sciences, 11(3):64-177 http://dx.doi.org/10.4038/jas.v11i3.8170

[18] Page, A.L., R.H. Millerand D.R. Keeney 1982. Methods of Soil Analysis: Part 2, Chemical and Microbiological Properties.(Eds) Agronomy Series No 9, American Society of Agronomy, Madison, WI.

file://C:/Users/Ali\%20Sharief/Downloads/booksagronomymonogra-methodsofsoilan2frontmatter.pdf

[19] Rehman, M.T.Khaliq, A. Ahmad, S.A.Wajid,F.Rasul, J. Hussain andS.Hussain 2014. Effect of Planting Time and Cultivar on Soybean Performancein Semi-Arid Punjab, Pakistan. Global Journal of Science Frontier Research: DAgriculture $\begin{array}{llll}\text { and } & \text { Veterinary, } & 14 & \text { (3): }\end{array}$ http://www.academia.edu/23666181/Effect_of_Plant ing_Time and_Cultivar_on_Soybean_Performance in_Semi-Arid_Punjab_Pakistan

[20] Sadeghi, S.M. and S. A. N. Niyaki 2013.Effects of planting date and cultivar on the yield and Yield components of soybean in north of Iran. ARPN Journal of Agricultural and Biological Science, 8(1): 81-85.

http://www.arpnjournals.com/jabs/research_papers/r p_2013/jabs_0113 518.pdf

[21] Shah,T., N. Z.Kalsoom, A. Ahmad and A. Jalal 2017. Yield and Quality Traits of Soybean Cultivars Response to Different Planting Windows.International Journal of Statistics and Actuarial Science, 1(3): 55-59. 이: $\underline{10.11648 / \text { j.ijsas.20170103.11 }}$

[22] Waller, R.A. andD.B. Duncan 1969. A Bayes Rule for the Symmetric Multiple Comparison Problem. Journal of the American Statistical Association 64: 1484-

1504.ttps://www.jstor.org/stable/2286085?seq=1\#pag e scan tab contents

[23] Yagoub, S. O. and M. H. A. Hamed 2013.Effect of Sowing Date on Two Genotypes of Soybean (Glycine max. Merrill.) Grown under Semi-desert Region. Universal Journal of Agricultural Research 1(3): 59-64.DOI: 10.13189/ujar.2013.010303 